\title{
Sistem Pengendalian Penanganan Kebakaran Gedung Menggunakan Metode Fuzzy
}

\author{
li Munadhif( ${ }^{(1)}$, Adianto $^{(2)}$, Ari Afrizal Mustofa ${ }^{(3)}$ \\ ${ }^{(1,2,3)}$ Program Studi Teknik Otomasi Politeknik Perkapalan Negeri Surabaya \\ (1)iimunadhif.its@gmail.com
}

\begin{abstract}
ABSTRAK
Kebakaran gedung adalah peristiwa penyebab kerusakan yang dapat terjadi kapanpun dan tidak dapat diprediksi. Kebakaran mengakibatkan kerugian materi dan korban jiwa. Faktor penyebab kebakaran antara lain korsleting listrik, kebocoran gas dan kelalaian manusia. Selain itu, penanganan lanjutan yaitu dengan bantuan mobil pemadam kebakaran. Namun, masyarakat sering sekali terlambat dalam menghubungi dan memberikan informasi tentang kondisi dan lokasi kepada petugas sehingga menyebabkan api semakin membesar. Oleh karena itu diperlukan suatu alat untuk pengendalian penanganan kebakaran gedung menggunakan sensor suhu, asap dan api dengan aktuator control valve dan buzzer menggunakan fuzzy. Input fuzzy berupa data suhu, asap, api dan outputnya adalah control valve dan buzzer sebagai alarm. Berdasarkan hasil pengujian, sensor suhu memiliki error 0,28\%, sensor asap memiliki nilai ADC semakin bertambah apabila terdeteksi asap, sensor api memiliki nilai ADC semakin berkurang apabila terdeteksi api. Control valve aktif secara proporsional sebagai pemadam api berdasarkan suhu, nilai kepekatan asap dan nilai api. Tingkat keberhasilan sistem pengendalian ini adalah 91,7\%.
\end{abstract}

Kata Kunci: kebakaran gedung, api, sensor, sistem pengendalian, fuzzy, aktuator.

Control System for Handling Building Fire Using Fuzzy Method

\begin{abstract}
Building fire is an event that causes damage that can occur at any time and is unpredictable. Fires cause material loss and loss of life. Factors that cause fire include electrical shortages, gas leakage and human negligence. In addition, further handling is with the help of fire trucks. However, the community is often too late in contacting and providing information about the conditions and location to officers, causing the fire to expand. Therefore, it is needed a tool to control building fire handling using temperature, smoke and fire sensors with control valve and buzzer actuators using fuzzy. Fuzzy input is data of temperature, smoke, fire and output data is the control valve and buzzer as an alarm. Based on the results of the test, the temperature sensor has a $0.28 \%$ error, the smoke sensor has an $A D C$ value increasing when smoke is detected, the fire sensor has an $A D C$ value decreasing when the fire is detected. The valve control is proportionally active as a fire extinguisher based on temperature, smoke density value and fire value. The success rate of this control system is $91.7 \%$
\end{abstract}

Keywords: buliding fire, fire, sensor, control system, fuzzy, actuator. 


\section{PENDAHULUAN}

Kebakaran gedung adalah salah satu peristiwa penyebab kerusakan yang dapat terjadi kapanpun dan tidak dapat diprediksi. Kebakaran dapat mengakibatkan banyak kerugian yaitu materi dan korban jiwa. Faktor penyebab kebakaran antara lain korsleting listrik, kebocoran gas yang mudah terbakar dan kelalaian manusia (Apriyaningsih dkk, 2017). Fire hydrant system dan fire sprinkler system merupakan instalasi pemadaman sebagai penanganan sementara saat terjadi kebakaran di beberapa tempat. Fire hydrant system merupakan instalasi pemadaman berupa pompa, selang dan air yang dapat digunakan untuk memadamkan api secara manual, sedangkan fire sprinkler system merupakan instalasi pemadaman yang bekerja otomatis berdasarkan suhu ruangan, namun kurang maksimal dikarenakan tanpa ada indikasi lainnya seperti asap dan api. Selain itu, penanganan lanjutan pemadaman kebakaran yaitu dengan bantuan mobil pemadam kebakaran. Namun, masyarakat sering sekali terlambat dalam menghubungi dan memberikan informasi tentang kondisi dan lokasi kepada petugas pemadam sehingga menyebabkan api semakin membesar. Dalam perkembangan teknologi dan informasi saat ini, akan sangat membantu apabila diterapkan sistem pemadaman api yang lebih optimal agar mengurangi peristiwa kebakaran. Pada penelitian ini, input yang digunakan adalah sensor DHT22 sebagai pendeteksi suhu, sensor MQ-2 sebagai pendeteksi gas atau asap berbahaya yang mudah terbakar, dan sensor api sebagai pendeteksi api. Dari input tersebut apabila terdeteksi adanya asap yang membahayakan adanya kebakaran, maka akan mengirimkan pesan kondisi gas atau asap yang berbahaya dan apabila terdeteksi suhu tinggi dan terdeteksi api maka aktuator control valve aktif secara proporsional berdasarkan logika fuzzy untuk memadamkan api dan buzzer sebagai alarm.

\section{METODE PENELITIAN}

a. Perancangan Sistem

Gambar 1 menunjukkan diagram blok perancangan sistem. Pada diagram tersebut memiliki tiga bagian penting yaitu masukan berupa data dari sensor DHT-22, sensor MQ-02, sensor api dan sensor GPS. Proses berupa pengendali wemos D1 mini dan keluaran berupa control valve dan buzzer.

Sensor DHT22 sebagai pendeteksi suhu ruangan, Sensor MQ-02 sebagai pendeteksi gas atau asap yang berbahaya, Sensor api sebagai pendeteksi api. Kemudian tiga data dari sensor tersebut akan diproses oleh mikrokontroler Wemos D1 untuk mengendalikan bukaan valve guna menyalurkan air dan mengaktifkan buzzer sebagai peringatan terjadinya kebakaran. Sistem ini memiliki 4 ruangan yang dilengkapi masing-masing sensor, pengendali dan aktuator.

\section{b. Perancangan Prototype Layout} Sistem

Prototype Layout sistem adalah tampilan perencanaan posisi pemasangan hardware pada masing-masing ruangan. Pada perencanaan ini pemasangan hardware diletakkan pada sisi tengah atas maket ruangan berukuran $125 \mathrm{~cm} \times 125 \mathrm{~cm} \times 50 \mathrm{~cm}$ yang berjumlah 4 ruangan. 


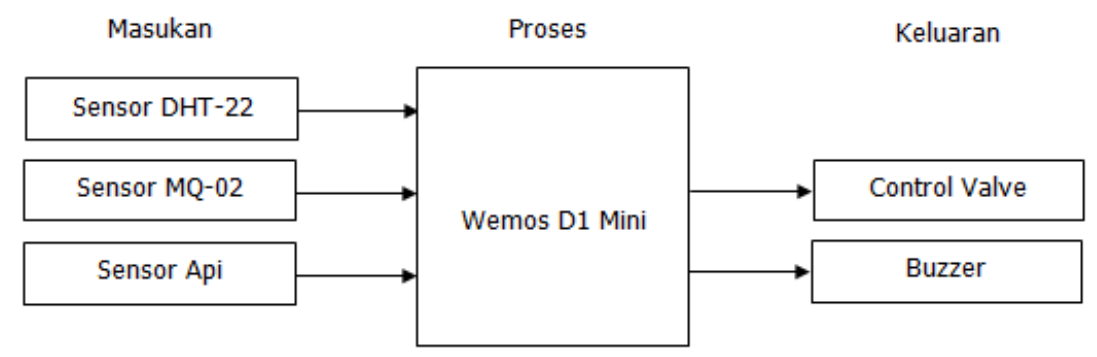

Gambar 1. Diagram blok perancangan sistem

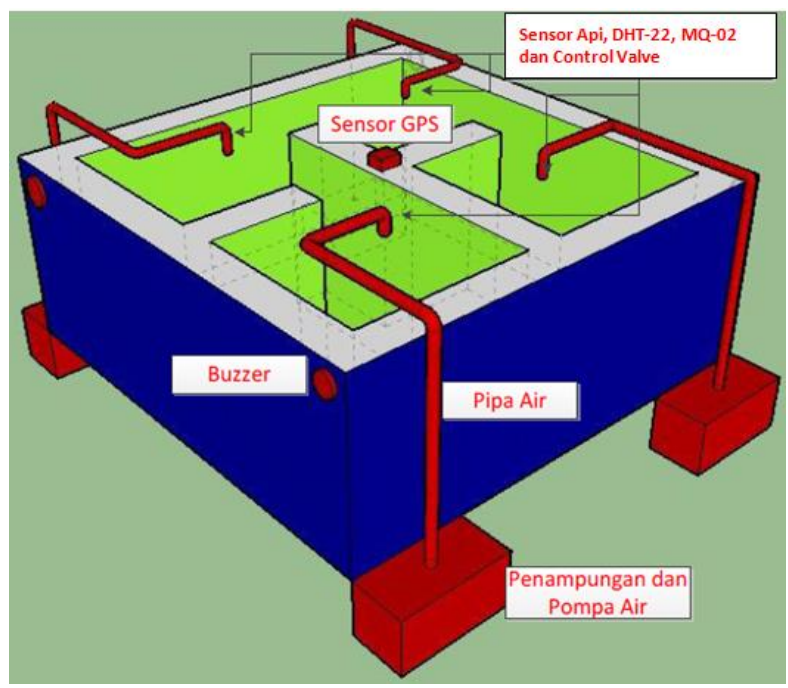

Gambar 2. Perancangan layout sistem

Pada setiap ruangan terdapat pipa dan control valve yang tersambung ke media penyimpanan air. Pada penyimpanan air tedapat pompa air sebagai penyalur air dari penampungan air untuk dialirkan pada setiap ruangan. Masing ruangan terdapat sensor api untuk mendeteksi api, sensor MQ-02 untuk mendeteksi asap, sensor DHT22 untuk mendeteksi suhu ruangan dan control valve sebagai tempat output penyaluran air dari penampungan air ke setiap ruangan. c. Perancangan Sensor DHT-22

Sensor DHT-22 adalah salah satu jenis sensor analog yang mengeluarkan tegangan analog sebagai representasi suhu ruangan untuk diteruskan ke wemos. Pada perancangan sensor ini digunakan untuk mengetahui rangkaian dari sensor ke wemos D1 mini sesuai dengan pinnya. Gambar 3 merupakan perancangan sensor DHT-22 ke wemos. Setelah perancangan, dilakukan pengujian kemampuan sensor dalam mendeteksi suhu. Data suhu dibandingkan dengan alat ukur HTC2. 


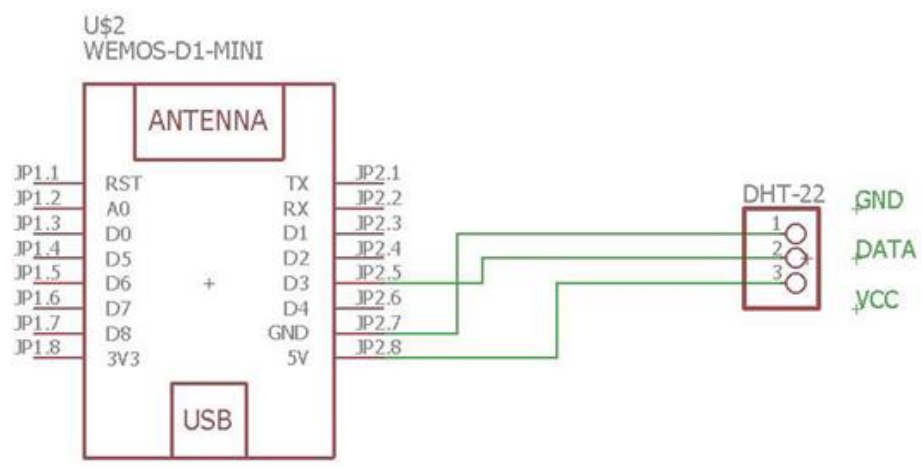

Gambar 3

Perancangan sensor DHT-22 ke wemos

Tabel 1

Perbandingan data sensor DHT-22 dengan alat ukur HTC-2

\begin{tabular}{cccc}
\hline Pengujian ke- & Suhu pada serial monitor $\left({ }^{\circ} \mathbf{C}\right)$ & Suhu pada alat ukur $\left({ }^{\circ} \mathbf{C}\right)$ & Error $(\%)$ \\
\hline 1 & 33,9 & 33,9 & 0 \\
2 & 33,9 & 33,9 & 0 \\
3 & 33,9 & 34 & 0,2 \\
4 & 33,9 & 33,9 & 0 \\
5 & 34,2 & 34,2 & 0 \\
6 & 34,4 & 34,2 & 0,5 \\
7 & 34,5 & 34,9 & 1,1 \\
8 & 34,5 & 34,8 & 0,8 \\
9 & 34,4 & 34,5 & 0,2 \\
10 & 68,5 & 34,2 & 0 \\
\hline
\end{tabular}

d. Perancangan Sensor MQ-02

Gambar 4 merupakan perancangan sensor MQ-02 ke wemos. Setelah perancangan, dilakukan pengujian kemampuan sensor dalam mendeteksi asap. Pengujian sensor asap MQ-02 ini dengan melakukan pengambilan data ADC yang didapat dari sensor kemudian diubah dalam bentuk satuan konsentrat kepekatan asap PPM (Part Per Million) dengan melakukan perhitungan yang didapat dari range nilai ADC yaitu $0-1023$ dan range dari datasheet sensor MQ-02 yaitu 300-10.000 PPM. Rumus perhitungannya adalah sebagai berikut:

$P P M=\frac{\text { nilai } A D C *(9700)}{1023-0}+300$
PPM adalah nilai kepekatan asap (PPM), dari persamaan 1 dapat dihitung nilai kepekatan asap dengan mengetahui nilai $A D C$ dari sensor MQ-02. Tabel 2 adalah data yang dihasilkan dari pengujian sensor dan nilai PPM hasil perhitungan.

Hasil pengujian pada Tabel 2 dilakukan 2 kondisi yaitu kondisi sensor MQ-02 tidak diberi asap rokok dan kondisi kedua sensor MQ02 diberikan asap rokok. Ketika tidak ada asap nilai ADC yang di dapat kurang dari 500 dan ketika diberikan asap rokok nilai ADC didapat lebih dari 500 dangan nilai konsentrat kepekatan asap yang semakin naik dan nilai ADC semakin naik berbanding lurus dengan banyaknya asap yang diterima oleh sensor. 


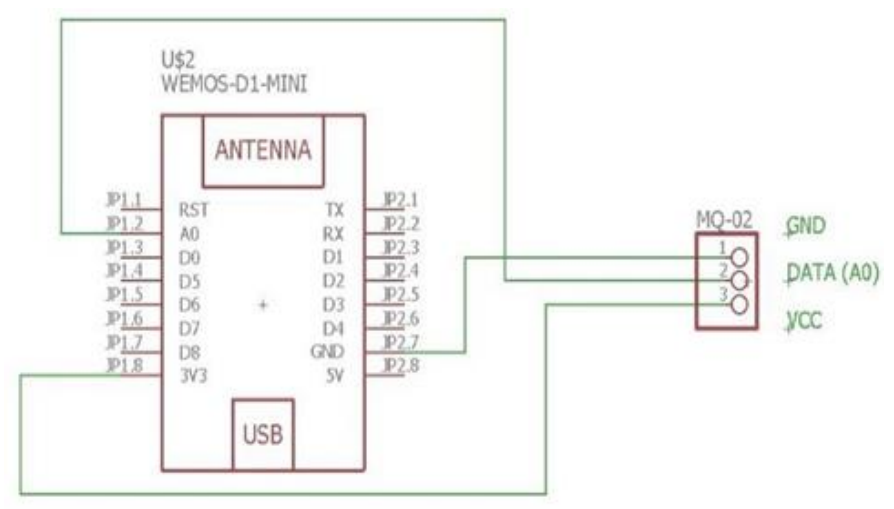

Gambar 4. Perancangan sensor MQ-02 ke wemos

Tabel 2. Data sensor MQ-02 dan nilai PPM

\begin{tabular}{ccccc}
\hline No. & \multicolumn{2}{c}{ Tidak ada asap } & \multicolumn{2}{c}{ Asap rokok } \\
& Nilai ADC & PPM & Nilai ADC & PPM \\
\hline 1 & 343 & 3552,2 & 783 & 7724,3 \\
2 & 343 & 3552,2 & 786 & 7752,7 \\
3 & 344 & 3561,7 & 788 & 7771,7 \\
4 & 344 & 3561,7 & 798 & 7866,5 \\
5 & 342 & 3542,8 & 788 & 7771,7 \\
6 & 343 & 3552,2 & 799 & 7876,0 \\
7 & 342 & 3542,8 & 801 & 7895,0 \\
8 & 341 & 3533,3 & 812 & 7999,3 \\
9 & 340 & 3523,8 & 814 & 8018,2 \\
10 & 339 & 3514,3 & 818 & 8056,2 \\
\hline
\end{tabular}

e. Perancangan Sensor Api

Perancangan sensor api ke wemos sama dengan perancangan sensor MQ-02 ke wemos yaitu gambar 4. Setelah perancangan, dilakukan pengujian kemampuan sensor dalam mendeteksi api. Pengujian dilakukan sebanyak lima kali pengujian pada setiap jarak yang berbeda dari sumber api. Pengujian sensor api ini dilakukan dengan pengambilan data ADC yang didapat dari sensor dan pengambilan data dari alat ukur intensitas cahaya yaitu alat ukur Light Meter.

Dari tabel 3, 4, dan 5 didapat parameter kondisi api jika terdapat api besar maka nilai ADC adalah kurang dari 300, terdapat api sedang nilai ADC adalah 400-600, terdapat api kecil nilai ADC adalah $600-800$ dan tidak ada api nilai ADC adalah 900-1024.

Tabel 3. Data sensor api dengan sumber api $10 \mathrm{~cm}$

\begin{tabular}{ccccc}
\hline No. & \multicolumn{2}{c}{ Tidak ada api } & \multicolumn{2}{c}{ Ada api } \\
& Nilai ADC & Light Meter (LUX) & Nilai ADC & Light Meter (LUX) \\
\hline 1 & 1024 & 8 & 75 & 23 \\
2 & 1024 & 9 & 72 & 22 \\
3 & 1024 & 8 & 69 & 24 \\
4 & 1024 & 8 & 68 & 24 \\
5 & 1024 & 9 & 64 & 25 \\
\hline
\end{tabular}


Tabel 4. Data sensor api dengan sumber api $20 \mathrm{~cm}$

\begin{tabular}{ccccc}
\hline No. & \multicolumn{2}{c}{ Tidak ada api } & \multicolumn{2}{c}{ Ada api } \\
& Nilai ADC & Light Meter (LUX) & Nilai ADC & Light Meter (LUX) \\
\hline 1 & 1024 & 9 & 480 & 16 \\
2 & 1024 & 8 & 512 & 16 \\
3 & 1024 & 8 & 544 & 15 \\
4 & 1024 & 9 & 607 & 16 \\
5 & 1024 & 8 & 734 & 17 \\
\hline
\end{tabular}

Tabel 5. Data sensor api dengan sumber api $30 \mathrm{~cm}$

\begin{tabular}{ccccc}
\hline No. & \multicolumn{2}{c}{ Tidak ada api } & \multicolumn{2}{c}{$\begin{array}{c}\text { Ada api } \\
\text { Light Meter (LUX) }\end{array}$} \\
\hline 1 & Nilai ADC & Light Meter (LUX) & Nilai ADC & $\begin{array}{c}2 \\
\text { Light }\end{array}$ \\
2 & 1024 & 9 & 890 & 13 \\
3 & 1024 & 10 & 834 & 12 \\
4 & 1024 & 8 & 832 & 11 \\
5 & 1024 & 8 & 845 & 13 \\
\hline
\end{tabular}

f. Perancangan Control Valve / Motor Servo

Motor servo digunakan sebagai media aktuator untuk mengatur pembukaan valve pada kran air. Motor servo adalah salah satu jenis aktuator analog yang memperoleh tegangan analog dari wemos. Putaran motor servo adalah $0^{\circ}$ sampai $90^{\circ}$ mewakili 0 sampai $100 \%$ bukaan valve. Suply tegangan dari wemos adalah 0 sampai 5 volt ekuivalen terhadap putaran motor servo yang dapat direpresentasikan pada gambar 5 .

\section{g. Perancangan Buzzer}

Gambar 6 merupakan perancangan aktuator buzzer dari wemos. Setelah perancangan, dilakukan pengujian kemampuan aktuator untuk mengetahui kinerjanya. Pengujian dilakukan dengan memberikan logika "1" dan " 0 " pada buzzer dari serial monitor. Pada penelitian ini, buzzer akan bernilai "1" jika keadaan menunjukkan bahaya. Hasil pengujian buzzer dengan memberikan logika 1 dan 0 ditunjukkan pada tabel 6 .

Saat buzzer diberi logic "1" pada serial monitor maka wemos akan memberikan sinyal/tegangan untuk mengaktifkan buzzer. Namun sebaliknya, saat buzzer diberi logic "0" maka buzzer akan mati karena tidak mendapatkan sinyal/tegangan dari wemos.

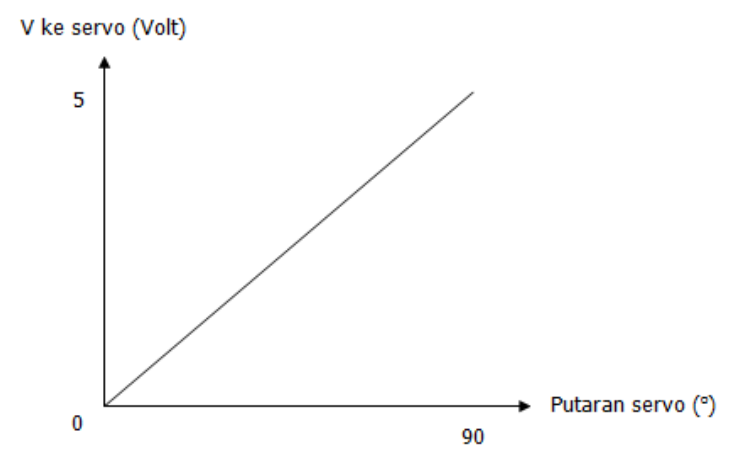

Gambar 5. Representasi putaran servo 


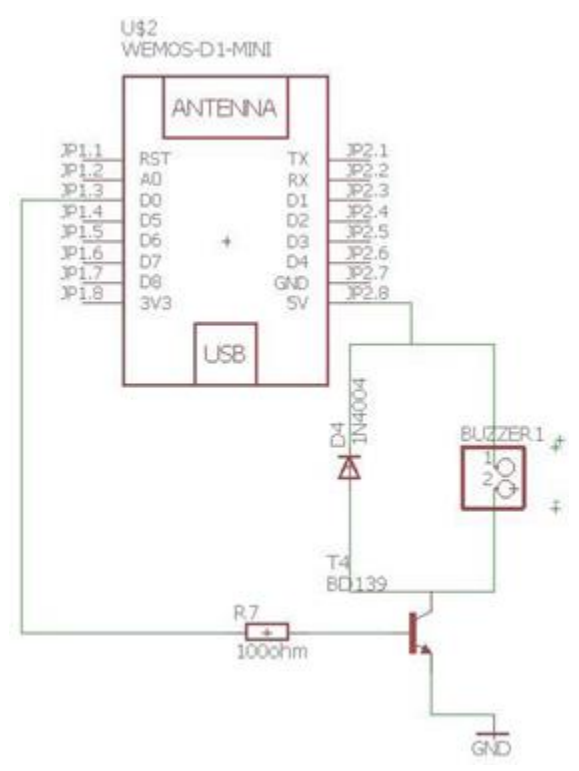

Gambar 6. Perancangan aktuator buzzer dari wemos

Tabel 6. Hasil pengujian buzzer

$\begin{array}{ccccc}\text { No. } & \text { Logika } & \text { Serial monitor } & \text { Buzzer } & \text { Keterangan } \\ 1 & 1 & \text { On } & \text { Bunyi } & \text { Benar } \\ 2 & 1 & \text { On } & \text { Bunyi } & \text { Benar } \\ 3 & 1 & \text { On } & \text { Bunyi } & \text { Benar } \\ 4 & 0 & \text { Off } & \text { Mati } & \text { Benar } \\ 5 & 0 & \text { Off } & \text { Mati } & \text { Benar } \\ 6 & 0 & \text { Off } & \text { Mati } & \text { Benar }\end{array}$

h. Perancangan Metode Fuzzy

Pada penelitian ini, metode fuzzy digunakan

untuk mengendalikan kinerja aktuator berdasarkan masukan dari data sensor. Tipe fuzzy yang digunakan adalah fuzzy sugeno orde nol. Masukan fuzzy terdiri dari tiga data sensor yaitu suhu, kadar asap dan api. Sedangkan keluaran fuzzy terdiri dari bukaan valve dan buzzer.

Masukan suhu, sensor DHT22 memiliki range pembacaan suhu yang cukup lebar yaitu -40 o sampai 80 o celcius. Masukan suhu dibagi menjadi tiga membership function(mf) yaitu dingin dengan range suhu -40 sampai 40 , sedang dengan range suhu 30 sampai 50 , dan panas dengan range 40 sampai 80. $\mathrm{mf}$ dingin dan panas menggunakan tipe trapesium, mf sedang menggunakan $\mathrm{mf}$ tipe segitiga. Membership function masukan suhu ditunjukkan pada gambar 7.

Masukan asap, sensor MQ02 memiliki range pembacaan asap 300 ppm sampai 10000 ppm. Masukan asap dibagi menjadi dua membership function(mf) yaitu tidak ada asap dengan range ppm 300 sampai 5000, ada asap dengan range ppm 4000 sampai 10000. Kedua mf menggunakan tipe trapesium. Membership function masukan asap ditunjukkan pada gambar 8 . 


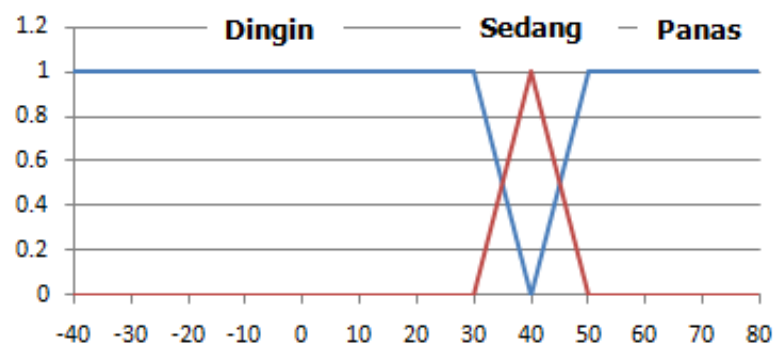

Gambar 7. Membership function masukan suhu

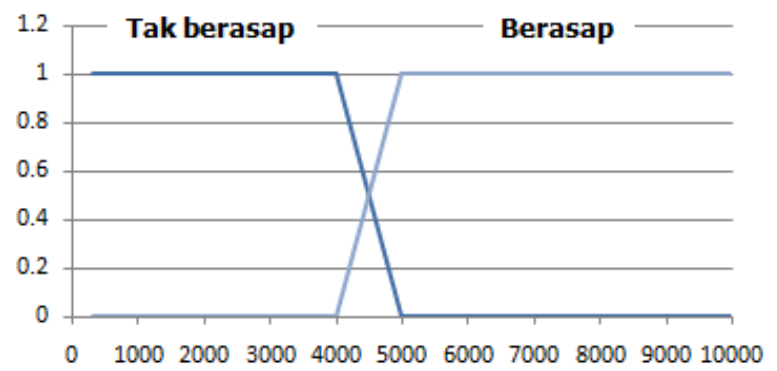

Gambar 8. Membership function masukan asap

$\begin{array}{ll}\text { Masukan api, gambar 9 } 9 & \text { function }(\mathrm{mf}) \text { yaitu lemah dengan } \\ \text { adalah membership function } & \text { range } 0 \text { sampai 15, sedang dengan } \\ \text { masukan api. Deteksi menggunakan } & \text { range suhu } 10 \text { sampai } 20 \text {, dan kuat } \\ \text { sensor api dipengaruhi oleh jarak } & \text { dengan range } 20 \text { sampai } 30 \text {. mf } \\ \text { sensor dengan sumber api. Sensor } & \text { lemah dan kuat menggunakan tipe } \\ \text { api memiliki range pembacaan lux } & \text { trapesium, mf sedang menggunakan } \\ \text { yaitu } 0 \text { smpai } 30 \text { lux. Masukan api } & \text { mf tipe segitiga. }\end{array}$
dibagi menjadi tiga membership

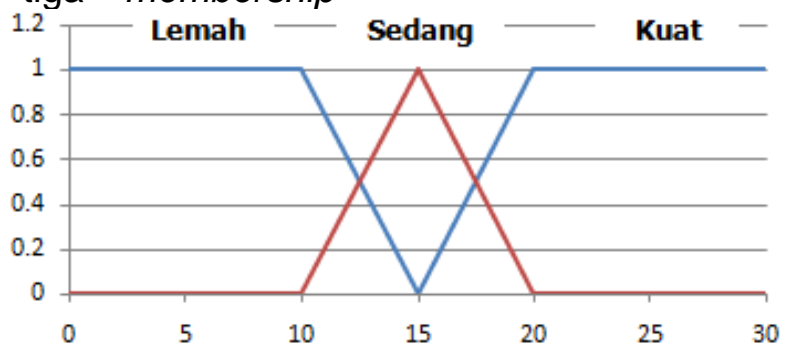

Gambar 9. Membership function masukan api

Keluaran control valve / bukaan motor servo, motor servo yang dicouple dengan bukaan valve memiliki range bukaan yaitu $0^{\circ}$ sampai $90^{\circ}$. Keluaran bukaan servo dibagi menjadi tiga membership function(mf) yaitu sempit dengan nilai 0 , sedang dengan nilai 45 , dan penuh dengan nilai 90 . Semua $\mathrm{mf}$ bernilai konstan.

Keluaran buzzer, buzzer memiliki logika 1 dan 0, akan tetapi perintah untuk memberi logika 1 atau 0 berdasarkan keluaran dari fuzzy. Perintah logika 1 jika kondisi bahaya, dan perintah 0 jika kondisi normal dan waspada. Kondisi normal, waspada dan bahaya ditentukan oleh keberadaan api, suhu dan asap pada ruangan. Pada buzzer memiliki tiga keluaran fuzzy yaitu 1, 2, dan 3. Keluaran 1 adalah kondisi normal, keluaran 2 adalah waspada, dan keluaran 2 adalah bahaya. 


\begin{tabular}{|c|c|c|c|c|c|c|}
\hline \multicolumn{7}{|c|}{$\begin{array}{c}\text { Tabel } 7 \\
\text { Rule bases }\end{array}$} \\
\hline & $\begin{array}{c}\text { Tidak } \\
\text { berasap dan } \\
\text { api lemah }\end{array}$ & $\begin{array}{c}\text { Tidak } \\
\text { berasap dan } \\
\text { api sedang }\end{array}$ & $\begin{array}{l}\text { Tidak } \\
\text { berasap dan } \\
\text { api kuat }\end{array}$ & $\begin{array}{l}\text { Berasap } \\
\text { dan api } \\
\text { lemah }\end{array}$ & $\begin{array}{l}\text { Berasap } \\
\text { dan api } \\
\text { sedang }\end{array}$ & $\begin{array}{c}\text { Berasap } \\
\text { dan api } \\
\text { kuat }\end{array}$ \\
\hline $\begin{array}{c}\text { Suhu } \\
\text { dingin }\end{array}$ & $\begin{array}{l}\text { Servo sempit } \\
\text { dan buzzer } \\
\text { normal }\end{array}$ & $\begin{array}{l}\text { Servo sedang } \\
\text { dan buzzer } \\
\text { waspada }\end{array}$ & $\begin{array}{l}\text { Servo penuh } \\
\text { dan buzzer } \\
\text { bahaya }\end{array}$ & $\begin{array}{c}\text { Servo } \\
\text { sempit dan } \\
\text { buzzer } \\
\text { waspada }\end{array}$ & $\begin{array}{l}\text { Servo } \\
\text { sedang dan } \\
\text { buzzer } \\
\text { waspada }\end{array}$ & $\begin{array}{c}\text { Servo } \\
\text { penuh dan } \\
\text { buzzer } \\
\text { bahaya }\end{array}$ \\
\hline $\begin{array}{l}\text { Suhu } \\
\text { sedang }\end{array}$ & $\begin{array}{l}\text { Servo sempit } \\
\text { dan buzzer } \\
\text { normal }\end{array}$ & $\begin{array}{l}\text { Servo sedang } \\
\text { dan buzzer } \\
\text { waspada }\end{array}$ & $\begin{array}{c}\text { Servo penuh } \\
\text { dan buzzer } \\
\text { bahaya }\end{array}$ & $\begin{array}{l}\text { Servo } \\
\text { sempit dan } \\
\text { buzzer } \\
\text { waspada }\end{array}$ & $\begin{array}{l}\text { Servo } \\
\text { sedang dan } \\
\text { buzzer } \\
\text { waspada }\end{array}$ & $\begin{array}{c}\text { Servo } \\
\text { penuh dan } \\
\text { buzzer } \\
\text { bahaya }\end{array}$ \\
\hline $\begin{array}{l}\text { Suhu } \\
\text { panas }\end{array}$ & $\begin{array}{l}\text { Servo sempit } \\
\text { dan buzzer } \\
\text { waspada }\end{array}$ & $\begin{array}{l}\text { Servo sedang } \\
\text { dan buzzer } \\
\text { bahaya }\end{array}$ & $\begin{array}{c}\text { Servo penuh } \\
\text { dan buzzer } \\
\text { bahaya }\end{array}$ & $\begin{array}{l}\text { Servo } \\
\text { sedang dan } \\
\text { buzzer } \\
\text { waspada }\end{array}$ & $\begin{array}{l}\text { Servo penuh } \\
\text { dan buzzer } \\
\text { bahaya }\end{array}$ & $\begin{array}{c}\text { Servo } \\
\text { penuh dan } \\
\text { buzzer } \\
\text { bahaya }\end{array}$ \\
\hline
\end{tabular}

Rule base fuzzy, rule bases pada fuzzy memiliki 18 aturan untuk memberikan perintah kepada aktuator agar penanganan terhadap kebakaran dengan menyemprot air segera dilakukan dan peringatan buzzer diberikan. Rule base tersebut ditunjukkan pada tabel 7 .

\section{HASIL DAN PEMBAHASAN}

Pada penelitian ini, pengujian setiap ruangan dilakukan dengan memberikan beberapa kondisi yang terdiri dari:Pengujian Normal, yaitu tanpa adanya gangguan asap dan api. Pengujian saat terdeteksi asap, yaitu adanya gangguan asap tanpa api. Pengujian saat terdeteksi asap dan api.

a. Hasil Pengujian Normal

Pengujian normal dilakukan dengan suhu dingin dan tanpa adanya gangguan asap dan api. Pengujian dilakukan pada masingmasing ruangan. Adapun hasil pengujian normal dapat ditunjukkan pada tabel 8.

Tabel 8. Hasil pengujian normal

\begin{tabular}{|c|c|c|c|}
\hline Ruangan & Kondisi plant & $\begin{array}{l}\text { Hasil pada serial } \\
\text { monitor }\end{array}$ & Keterangan \\
\hline 1 & & $\begin{array}{l}\text { Masukan } \\
\text { Suhu } 28^{\circ} \mathrm{C} \\
\text { Asap } 3552,2 \text { PPM } \\
\text { Api } 8 \text { lux } \\
\text { Keluaran } \\
\text { Sudut servo } 0^{\circ} \\
\text { Buzzer } 1\end{array}$ & $\begin{array}{l}\text { Ketika diberi suhu dingin } 28^{\circ} \mathrm{C} \text {, } \\
\text { tidak ada asap } 3552,2 \text { PPM } \\
\text { dan tidak ada api } 8 \text { lux, kondisi } \\
\text { valve } 0^{\circ} \text { masih menutup dan } \\
\text { buzzer } 1 \text { artinya normal / tidak } \\
\text { menyala }\end{array}$ \\
\hline 2 & & $\begin{array}{l}\text { Masukan } \\
\text { Suhu } 28^{\circ} \mathrm{C} \\
\text { Asap } 3562 \text { PPM } \\
\text { Api } 9 \text { lux } \\
\text { Keluaran }\end{array}$ & $\begin{array}{l}\text { Ketika diberi suhu dingin } 28^{\circ} \mathrm{C} \text {, } \\
\text { tidak ada asap } 3562 \mathrm{PPM} \text { dan } \\
\text { tidak ada api } 9 \text { lux, kondisi } \\
\text { valve } 0^{\circ} \text { masih menutup dan } \\
\text { buzzer } 1 \text { artinya normal / tidak } \\
\text { menyala }\end{array}$ \\
\hline
\end{tabular}

Sudut servo $0^{\circ}$

Buzzer 1 


\begin{tabular}{|c|c|c|c|}
\hline Ruangan & Kondisi plant & $\begin{array}{c}\text { Hasil pada serial } \\
\text { monitor }\end{array}$ & Keterangan \\
\hline 3 & & $\begin{array}{l}\text { Masukan } \\
\text { Suhu } 28^{\circ} \mathrm{C} \\
\text { Asap } 3555 \text { PPM } \\
\text { Api } 9 \text { lux } \\
\text { Keluaran } \\
\text { Sudut servo } 0^{\circ} \\
\text { Buzzer } 1\end{array}$ & $\begin{array}{l}\text { Ketika diberi suhu dingin } 28^{\circ} \mathrm{C} \text {, } \\
\text { tidak ada asap } 3555 \text { PPM dan } \\
\text { tidak ada api } 9 \text { lux, kondisi } \\
\text { valve } 0^{\circ} \text { masih menutup dan } \\
\text { buzzer } 1 \text { artinya normal / tidak } \\
\text { menyala }\end{array}$ \\
\hline 4 & & $\begin{array}{l}\text { Masukan } \\
\text { Suhu } 28^{\circ} \mathrm{C} \\
\text { Asap } 3552,2 \text { PPM } \\
\text { Api } 9 \text { lux } \\
\text { Keluaran } \\
\text { Sudut servo } 0^{\circ} \\
\text { Buzzer } 1\end{array}$ & $\begin{array}{l}\text { Ketika diberi suhu dingin } 28^{\circ} \mathrm{C} \text {, } \\
\text { tidak ada asap } 3552,2 \text { PPM } \\
\text { dan tidak ada api } 9 \text { lux, kondisi } \\
\text { valve } 0^{\circ} \text { masih menutup dan } \\
\text { buzzer } 1 \text { artinya normal / tidak } \\
\text { menyala }\end{array}$ \\
\hline
\end{tabular}

Dari tabel 8, sistem tidak memberikan respon untuk mengaktifkan bukaan valve dan buzzer masih dalam keadaan normal.

b. Hasil pengujian saat terdeteksi asap
Pengujian saat terdeteksi asap dilakukan dengan memberikan kondisi asap berbahaya yang menyebabkan kebakaran yaitu memberi asap rokok pada ruangan yang akan diuji. Adapun hasil pengujian saat terdeteksi asap dapat ditunjukkan pada tabel 9 .

Tabel 9. Hasil pengujian saat terdeteksi asap

Ruangan

\section{Hasil pada serial} monitor

\section{Masukan}

Suhu $28,5^{\circ} \mathrm{C}$

Asap 3667 PPM

Api 8 lux

Keluaran

Sudut servo $0^{\circ}$

Buzzer 1

Masukan

Suhu $28^{\circ} \mathrm{C}$

Asap 7562 PPM

Api 9 lux

Keluaran

Sudut servo $0^{\circ}$

Buzzer 2
Ketika diberi suhu dingin $28^{\circ} \mathrm{C}$, tidak ada asap 7562 PPM dan tidak ada api 9 lux, kondisi valve $0^{\circ}$ masih menutup dan buzzer 2 artinya waspada / tidak menyala 


\begin{tabular}{|c|c|c|c|}
\hline Ruangan & Kondisi plant & $\begin{array}{c}\text { Hasil pada serial } \\
\text { monitor }\end{array}$ & Keterangan \\
\hline 3 & & $\begin{array}{l}\text { Masukan } \\
\text { Suhu } 29^{\circ} \mathrm{C} \\
\text { Asap } 7842 \text { PPM } \\
\text { Api } 9 \text { lux } \\
\text { Keluaran } \\
\text { Sudut servo } 0^{\circ} \\
\text { Buzzer } 2\end{array}$ & $\begin{array}{l}\text { Ketika diberi suhu dingin } 29^{\circ} \mathrm{C} \text {, } \\
\text { tidak ada asap } 7842 \mathrm{PPM} \text { dan } \\
\text { tidak ada api } 9 \text { lux, kondisi } \\
\text { valve } 0^{\circ} \text { masih menutup dan } \\
\text { buzzer } 2 \text { artinya waspada / } \\
\text { tidak menyala }\end{array}$ \\
\hline 4 & & $\begin{array}{l}\text { Masukan } \\
\text { Suhu } 28^{\circ} \mathrm{C} \\
\text { Asap } 8103 \text { PPM } \\
\text { Api } 8 \text { lux } \\
\text { Keluaran } \\
\text { Sudut servo } 0^{\circ} \\
\text { Buzzer } 2\end{array}$ & $\begin{array}{l}\text { Ketika diberi suhu dingin } 28^{\circ} \mathrm{C} \text {, } \\
\text { tidak ada asap } 8103 \text { PPM dan } \\
\text { tidak ada api } 8 \text { lux, kondisi } \\
\text { valve } 0^{\circ} \text { masih menutup dan } \\
\text { buzzer } 2 \text { artinya waspada } / \\
\text { tidak menyala }\end{array}$ \\
\hline
\end{tabular}

Dari tabel 9 , pada ruangan 1 belum diberi asap sehingga tidak memberikan respon untuk mengaktifkan bukaan valve dan buzzer masih dalam keadaan normal. Pada ruangan 2,3, dan 4 diberi asap dengan nilai kepekatan asap yang berbeda, namun bukaan valve masih 0 dan buzzer memberi peringatan waspada tapi tidak menyalakan alarm.

c. Hasil pengujian saat terdeteksi asap dan api
Pengujian saat terdeteksi asap dan api dilakukan dengan memberikan kondisi asap berbahaya yang menyebabkan kebakaran yaitu memberi asap rokok pada ruangan yang akan diuji dan memberikan api dengan membakar kertas dengan jarak $<10 \mathrm{~cm}$. Adapun hasil pengujian saat terdeteksi asap dan api dapat ditunjukkan pada tabel 10.

Tabel 10. Hasil pengujian saat terdeteksi asap dan api

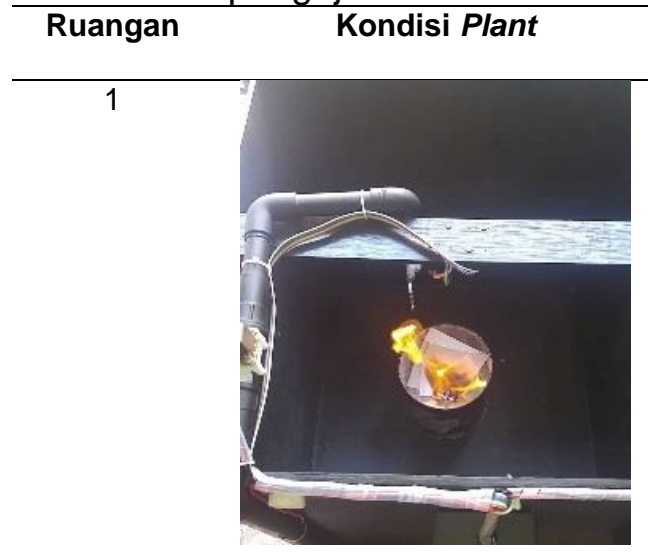

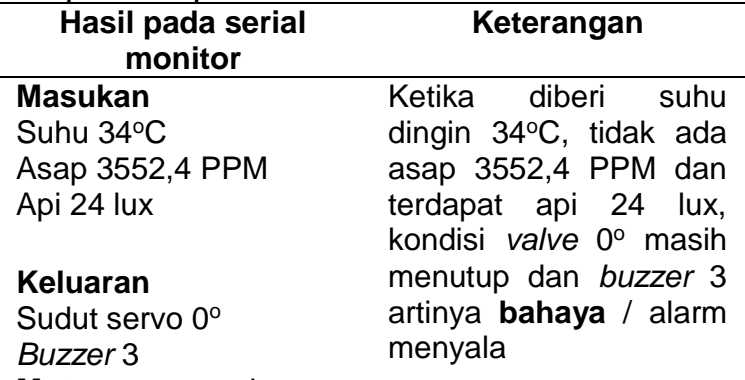

Motor servo pada

ruangan 1 mengalami

error sehingga tidak

membukakan valve 
2

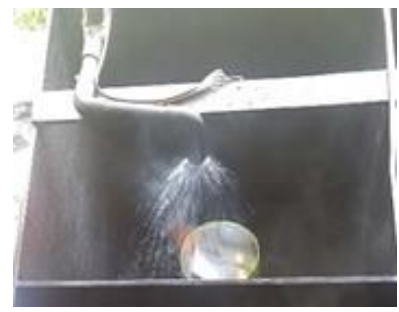

3

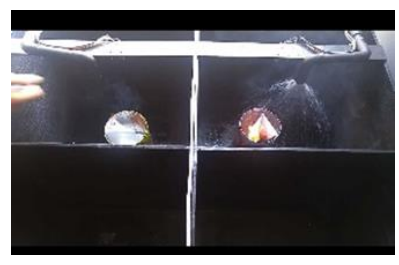

4

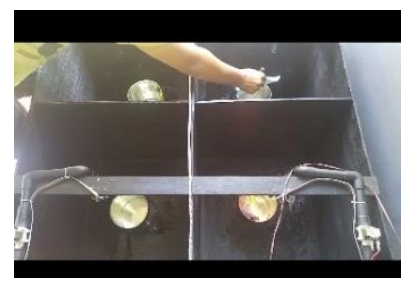

Masukan

Suhu $35^{\circ} \mathrm{C}$

Asap 3611 PPM

Api 22 lux

Keluaran

Sudut servo $90^{\circ}$

Buzzer 3

Masukan

Suhu $39^{\circ} \mathrm{C}$

Asap 3589 PPM

Api 26 lux

Keluaran

Sudut servo $90^{\circ}$

Buzzer 3

Masukan

Suhu $38^{\circ} \mathrm{C}$

Asap 8232 PPM

Api 26 lux

Keluaran

Sudut servo $90^{\circ}$

Buzzer 3
Ketika diberi suhu dingin $35^{\circ} \mathrm{C}$, tidak ada asap 3611 PPM dan terdapat api 22 lux kondisi valve $90^{\circ}$ membuka dan buzzer 3 artinya bahaya / alarm menyala

Ketika diberi suhu dingin $39^{\circ} \mathrm{C}$, tidak ada asap 3589 PPM dan terdapat api 26 lux, kondisi valve $90^{\circ}$ membuka dan buzzer 3 artinya bahaya / alarm menyala

Ketika diberi suhu dingin $38^{\circ} \mathrm{C}$, tidak ada asap 8232 PPM dan terdapat api 26 lux, kondisi valve $90^{\circ}$ membuka dan buzzer 3 artinya bahaya / alarm menyala
Dari tabel 10 , pada ruangan 1 diberi api tapi motor servo tidak memberikan respon untuk mengaktifkan bukaan valve dikarenakan error motornya dan buzzer dalam kondisi bahaya. Pada ruangan 2 dan 3 diberi api dengan jarak api $<10 \mathrm{~cm}$ sehingga valve membuka 900 dan buzzer memberi peringatan bahaya dan menyalakan alarm. Pada ruangan 4 diberi asap dan api sehingga motor servo membuka 90o dan buzzer dalam kondisi bahaya dan menyalakan alarm. Secara keseluruhan sebanyak 12 kali pengujian dengan berbagai kondisi, kemampuan alat untuk mematikan api berhasil 11 kali sehingga diperoleh persentase keberhasilan sistem pengendalian ini adalah sebagai berikut:

$$
P K=\frac{n \text { berhasil }}{n \text { total }} * 100 \%
$$

Dimana PK adalah persentase keberhasilan (\%), $\mathrm{n}$ berhasil sebanyak $11 \mathrm{x}$ dari $\mathrm{n}$ total $12 \mathrm{x}$ sehingga diperoleh persentase keberhasilannya adalah $91,7 \%$.

\section{KESIMPULAN}

Sistem pengendalian kebakaran berdasarkan masukan suhu, kepekatan asap dan api serta keluaran bukaan valve/motor servo dan buzzer telah berhasil dilakukan, pengujian dilakukan dengan tiga kondisi yaitu normal tanpa asap dan api, terdapat asap tanpa api, dan terdapat asap dan api. 4 ruangan diuji berdasarkan kondisi masingmasing, pada kondisi normal, sistem mampu mendeteksi ketiadaan asap dan api sehingga valve menutup dan buzzer keadaan normal. Pada kondisi terdapat asap, sistem mampu mendeteksi asap sehingga valve masih menutup dan buzzer keadaan waspada. Pada kondisi terdapat asap dan api, sistem mampu membuka valve di ruangan 2,3 , dan 4 namun tidak berhasil di ruangan 1 dan buzzer keadaan bahaya sehingga diperoleh persentase keberhasilan sistem pengandalian adalah $91,7 \%$.

\section{DAFTAR PUSTAKA}

Apriyaningsih, Mega, Abdul Muid, Nurhasanah. (2017). Prototype Sistem Pemadam Kebakaran Otomatis Berbasis Mikrokontroler Atmega328p. Jurnal PRISMA FISIKA, Vol. V, No. 3:106-110.

Handoko, Selamet, I. Hestiningsih, R. Prasetya, W. A. Arrosyidi (2012). 
Prototype Alat Pemberi Informasi Jarak Antar Kendaraan.

Handy, Dendy, Nida, Hanif, Gagat,Sofyan, Ade, Heriyanto, Ardian, Irzaman (2016). Pembuatan Model Pendeteksi Api Berbasis Arduino Uno Dengan Keluaran SMS GATEWAY.

Satpandi, A. H. (2014). Perbandingan Akurasi Pengukuran Suhu dan Kelembaban Antara Sensor DHT11 dan DHT22. Jurnal Infotel.
Syam Ph.D, Rafiuddin (2013) Dasar Dasar Teknik Sensor, Makassar.

Tryadi, Rocky, Dedi Trianto, Ilhamsyah (2015). Prototype system Kran Air Otmatis Berbasis Sensor Flowmeter Pada Gedung Bertingkat.

Zain, Abdul. (2016). Rancang Bangun Sistem Proteksi Kebakaran Menggunakan Smoke dan Heat Detector.Jurnal INTEK. Vol 3 (1): 36-4 